\title{
THE APPLICATION OF A JET FAN FOR THE CONTROL OF AIR AND METHANE STREAMS MIXING AT THE EXCAVATIONS CROSS - THE RESULTS OF NUMERICAL SIMULATION
}

\author{
Paweł WRONA, Zenon RÓŻAŃSKI, Grzegorz PACH, Lech DOMAGAŁA \\ Silesian University of Technology
}

\begin{abstract}
:
The paper presents the results of numerical simulations into the distribution of methane concentration at the intersection of two excavations with a fan (turned on) giving the air stream to the area of the crossing. Assumed case represents emergency situation related to the unexpected flow of methane from an excavation and its mixing with fresh air. It is possible when sudden gas outburst takes place, methane leaks from methane drainage system or gas leaks out the pipelines of underground coal gasification devices. Three options were considered - corresponding to three different speeds of the jet fan. They represent three stages of fan work. First - low air speed is forced by a pneumatic fan, when electricity is cut off after high methane concentration detection. Medium speed can be forced by pneumatic-electric device when methane concentration allows to turn on the electricity. Third, the highest speed is for electric fans. Simulations were carried out in the Fire Dynamics Simulator (FDS) belongs to the group of programs Computational Fluid Dynamics (CFD). The governing equations are being solved in a numerical way. It was shown that proposed solution allows partial dilution of methane in every variant of speed what should allow escape of the miners from hazardous area.
\end{abstract}

Key words: CFD simulation, methane, gas hazard, jet fan

\section{INTRODUCTION}

There are at least two reasons for giving particular attention to methane. First, it is the naturally occurring gas that most commonly appears in mined underground openings. Secondly, it has resulted in more explosions and related loss of life than any other cause throughout the recorded history of mining [10].

According to significant and constantly rising methane hazard in Polish underground coal mines [14], the topic is referred to simulations and measurements of mine gas flow which are taken into consideration very often. Different aspects of the research are examined. They are as follows:

- changes of methane concentration in total amount of mine gas $[2,3,6,11]$,

- variability of velocity fields and possibilities of their forecasting [11],

- acquiring knowledge about unexpected and emergency states of mine ventilation net $[5,7,11,12]$.

Methane emitted from the strata into a mine opening will often be at concentrations in excess of 90 percent. While being diluted down to safe concentrations, the methane will, inevitably, pass through the 5 to 15 percent range during which time it is explosive [13]. The buoyancy of methane with respect to air produces a tendency for concentrated methane to collect in roof cavities and to layer along the roofs of airways or working faces [10].

The most dangerous mode of gas emission into mine workings is the release of large volume of gas from the strata in a short period of time. It is called gas outburst. Such incidents have caused considerable loss of life [10].
Another possible mode is unexpected gas leak, e.g. from methane drainage system or form underground coal gasification pipelines.

Such a case was taken into the consideration. In underground net of excavations sudden methane leak or outburst is assumed. In the consequence, the mixture of methane and the air flows to an excavation where miners usually work. It is also assumed that sensor is set up in proper place to give the signal for turn on a jet fan mounted at the intersection (a cross) of excavations. It should cause dilution of dangerous mixture and will give proper time for the escape.

CFD simulations fit every aspect of mine gas flowing through a ventilation net, and detailed analysis of their suitability for mine ventilation purposes has been checked out, too [4].

This article gives the results of simulation into application of a jet fan which is mounted at the cross of two perpendicular excavations, under the roof. The fan gives right direction and partial dilution during mixing of the streams when one of the streams has high and dangerous concentration of methane.

The simulation was carried out with Fire Dynamics Simulator (FDS) and its visual mode Pyrosim. This software belongs to the group of CFD programs and it is based (as the others) on solving Navier-Stokes formulas. However, regardless the basic destination for FDS, (which is particularly designed for the fire simulation), it can be also applied for air flow analysis, when the flow is not forced by the fire 
P. WRONA, Z. RÓŻAŃSKI, G. PACH, L. DOMAGAŁA - The application of a jet fan for the control of air and methane streams...

phenomenon. FDS has been tested for mine ventilation simulations, e.g. [15] with positive results.

\section{FIRE DYNAMICS SIMULATOR (FDS) - THE PRINCIPLES AND ASSUMPTIONS}

In this chapter the principles of FDS model, solver and the assumptions for the simulations are described.

\section{General characteristics of FDS}

Considering fluid mechanics, an approximate form of the Navier-Stokes equations appropriate for low Mach number applications is used in the model [9]. Solving of Navier-Stokes equations is done by numerical method for each node of a mesh and further approximation of obtained results between the nodes for each iteration. The conservation equations for mass, momentum and energy for a Newtonian fluid are presented in the model $[1,8,9]$. Equation of state for a perfect gas is included, too [16].

The computation can either be treated as a Direct Numerical Simulation (DNS), in which the dissipative terms are computed directly, or as a Large Eddy Simulation (LES), in which the large-scale eddies are computed directly and the subgrid-scale dissipative processes are modeled. The most distinguishing feature of any CFD model is its treatment of turbulence. The conception of LES (including turbulence) is making averaging out the influence of small eddy (vortex), (independent from geometry) and putting them into calculations as additional components of tension, just looking only for solutions for big eddy (which are dependent on geometry, boundary conditions etc.) [9].

For reduction of time during computing and decrease of number of calculations done by mathematical model of FDS, it has a lot of simplifications. The most important are:

- the assumption of small velocities,

- cuboid geometry of computation domain,

- limitation of the fire growth and spread,

- the assumption of combustion with unlimited oxygen access,

- limitation of heat radiation.

According to simulations of flow without the fire, only points 'a' and 'b' matter.

\section{The assumptions}

Created model consists of the cross of two underground excavations, which geometry is given in Fig. 1. Following assumptions are set for further computing.

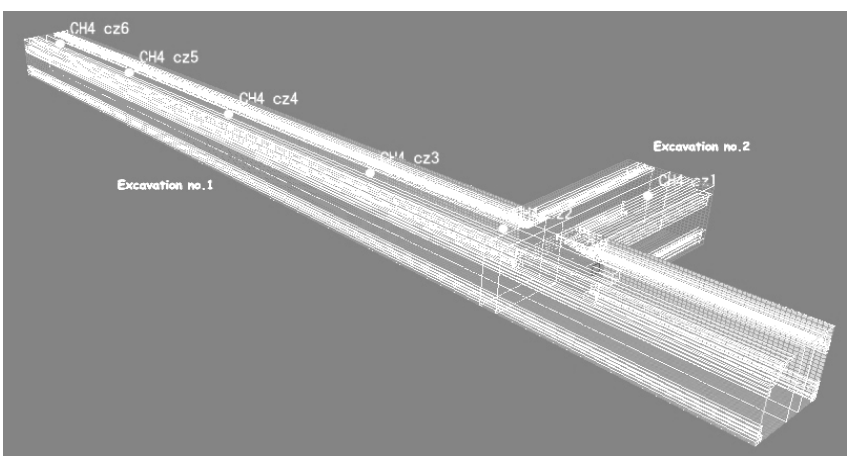

Fig. 1 The scheme of the model

Model dimensions:

- the excavation no. 1 - the length $70 \mathrm{~m}(\mathrm{Y})$, the width $5 \mathrm{~m}(\mathrm{X})$, the height $4 \mathrm{~m}(\mathrm{Z})$.

- the excavation no. 2 - the length $10 \mathrm{~m}(\mathrm{X})$, the width $5 \mathrm{~m}(\mathrm{Y})$, the height $4 \mathrm{~m}(\mathrm{Z})$.
The length of computational cell was set at $0.2 \mathrm{~m}$, according to [9] as dimension qualified between coarse and fine. In addition, the mesh was compacted near the roof (cell length equaled $0.1 \mathrm{~m}$ ) to check and compare the results with application of such a non-uniform mesh. The aim was to obtain reliable results within reasonable time. The comparison at slice $X=5 \mathrm{~m}$ for the excavation no. 1 is shown in Fig. 2.

During the analysis of the results it was found that there is the similar maximal $\mathrm{CH}_{4}$ concentration under the roof, which was $7 \%$ vol., and contour of the mixture of methane - air is also similar in both options of mesh size. It was the base for the decision of application of the uniform mesh with a cell length $0.2 \mathrm{~m}$ for further simulations. However, this is one of the simplifications of the model.

The length of cell equals $0.2 \mathrm{~m}$ gave 175000 cells for excavation no. 1 and 26000 cells for excavation no. 2 .

The excavation no. 2 is connected with the excavation no.1 at the distance $10 \mathrm{~m}$ from the assumed beginning of this excavation. The shape of both excavations is adequate to $Ł P$ support. Two kinds of pre-defined materials were used in the model. The first was "rock", the second was "steel". "Steel" was applied for the support and for the rotator of the fan. As both materials are predefined in the program this is the another simplification, although because of lack of the fire and in consequence intensive heat exchange, this simplification can be accepted. Heat exchange between the rock-mass and the air is not included, too.

Two airstreams flow from the excavations no. 1 and the excavation no. 2 and they mix up at the cross. The parameters of stream 1 (flowing through the excavation no. 1): dry bulb temperature $t_{d}=24^{\circ} \mathrm{C}$, average velocity $w_{a v}=3.0 \mathrm{~m} / \mathrm{s}$, methane concentration $\mathrm{CH}_{4}=0 \%$ vol, the rest of the air stream is filled with fresh air.

The parameters of stream 2 (flowing through the excavation no. 2) are: $t_{d}=28^{\circ} \mathrm{C}, w_{a v}=0.3 \mathrm{~m} / \mathrm{s}, \mathrm{CH}_{4}=10 \%$ obj., the rest of the air stream is filled with fresh air.

Three variants were connected with intensity of work of the jet fan (its hydraulic diameter is $D=0.6 \mathrm{~m}$ ). The variants are:

1. The fan forming volume flow $V^{\prime}=3.0 \mathrm{~m}^{3} / \mathrm{s}$, which is related to average velocity $w_{a v}=8.33 \mathrm{~m} / \mathrm{s}$.

2. The fan forming volume flow $V^{\prime}=6.0 \mathrm{~m}^{3} / \mathrm{s}$, which is related to $\mathrm{w}_{\mathrm{av}}=16.66 \mathrm{~m} / \mathrm{s}$.

3. The fan forming volume flow $V^{\prime}=12.6 \mathrm{~m}^{3} / \mathrm{s}$, which is related to $\mathrm{w}_{\mathrm{av}}=35 \mathrm{~m} / \mathrm{s}$.

The lowest value of volume flow (variant 1) can be achieved with application of a pneumatic fan, e.g. WLP 403SK when electricity is shut down after detection of high methane concentration. Medium value of volume flow (variant 2) can be achieved by an electro-pneumatic fan e.g. WLEP - 605 or WWOE - 630. The highest value of volume flow (variant 3) can be generated by electric fan e.g. WLE $1006 \mathrm{~A} / 1 / \mathrm{SK}$. The fan is mounted $1.2 \mathrm{~m}$ from right side of the excavation, $0.45 \mathrm{~m}$ from the cross and its base is set at the height of $2.6 \mathrm{~m}$.

Methane detectors are included in the model. They are located at the beginning of the excavation no. 1 (sensor $c z 1$ ), at the cross (sensor cz2) and next sensors (numerous cz3, cz4, cz5 and cz6) at the following distances: $10 \mathrm{~m}, 25$ $\mathrm{m}, 40 \mathrm{~m}$ i $55 \mathrm{~m}$ from the cross. In addition, animated slices for $\mathrm{CH}_{4}$ were set up at the distances $\mathrm{X}=2.6 \mathrm{~m}$, and $\mathrm{Y}=2.6$ $\mathrm{m}$. Large Eddy Simulations mode was set for the calculations. The time equaled 180 seconds. 


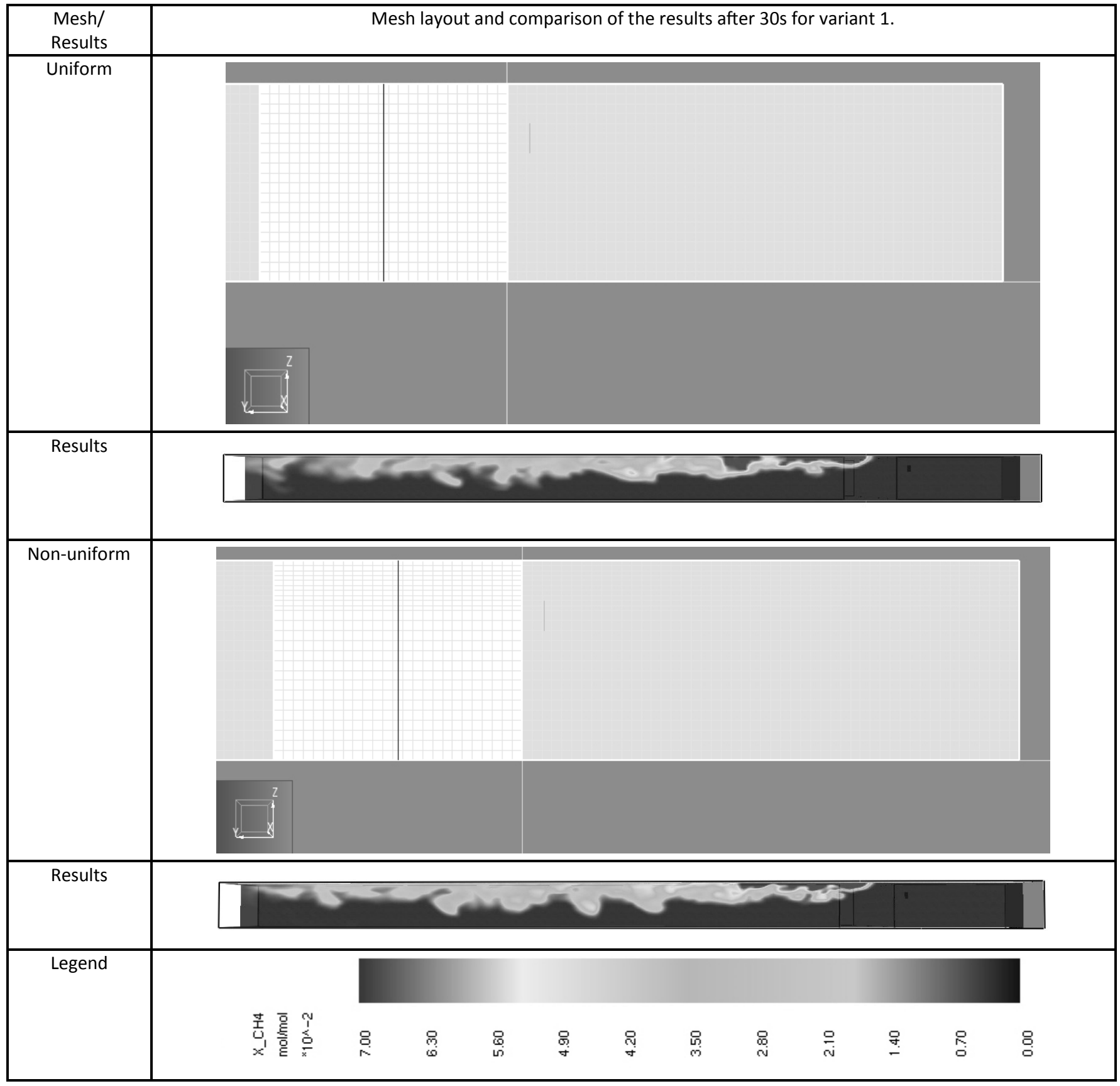

Fig. 2 Comparison of results obtained with uniform and non-uniform mesh for the excavation no. 1, after 30s of simulation for variant 1

\section{THE RESULTS AND ANALYSIS}

The figures 3-6 show comparison of methane concentration at slices $Y=2.6 \mathrm{~m}, \mathrm{X}=2.6 \mathrm{~m}$ (the model is built in $\mathrm{X}$, $Y, Z$ system of coordinates), after 60 seconds, 120 seconds and 180 seconds of simulation,

Figure 3 shows methane concentration in the excavation no. 2 (source of methane leak, with the concentration $\mathrm{CH}_{4}=10 \%$ vol). Constant and stable flow of this gas through boundary surface is another simplification in the model, although considering density of methane, just after $2 \mathrm{~m}$ from the boundary surface, proper stratification of methane - air mixture can be noticed (see Fig. 3 under the roof). Sufficient legend due to colors explanation is included to every figure.

Each variant makes partial gauge pressure area in the excavation no.1, thus the visualization of the results for the next time steps allows to observe descending of methane - air mixture in the excavation no. 2. It also leads to increase of methane concentration in the excavation no. 1 , near the excavation no. 2.

In every variant for the excavation no. 2, after $180 \mathrm{sec}-$ onds of simulation the concentration of methane is always higher than $2 \%$ vol. (turning of the electricity according to Polish underground regulations). Although, it is easy to observe significant stratification of gases in the excavation no. 2. Considering the area of the excavation which is filled with the methane of the lowest concentration, it can be noticed that the first variant gives the largest area of that kind and the third variant gives the smallest one.

On the other hand, looking into results from the excavation no. 1 (Fig. 3), every variant gave efficient dilution of methane in near-roof area near the cross. Concentration of methane $10 \%$ vol. was detected only under the roof, within small area, near the inlet of the excavation no. 2. 
P. WRONA, Z. RÓŻAŃSKI, G. PACH, L. DOMAGAŁA - The application of a jet fan for the control of air and methane streams...

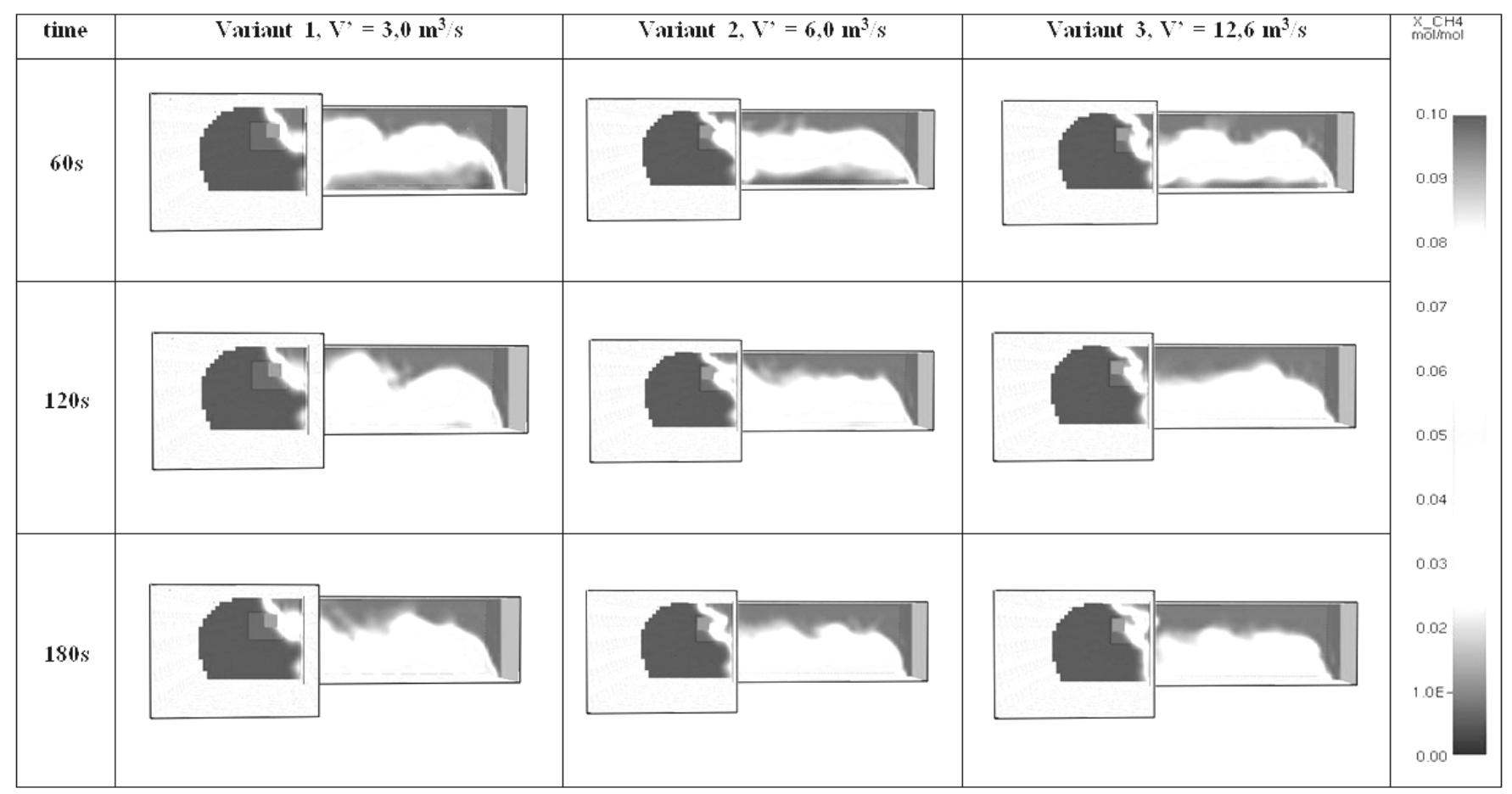

Fig. 3 The results of $\mathrm{CH}_{4}$ concentration in excavation no. 2 for different simulation variants

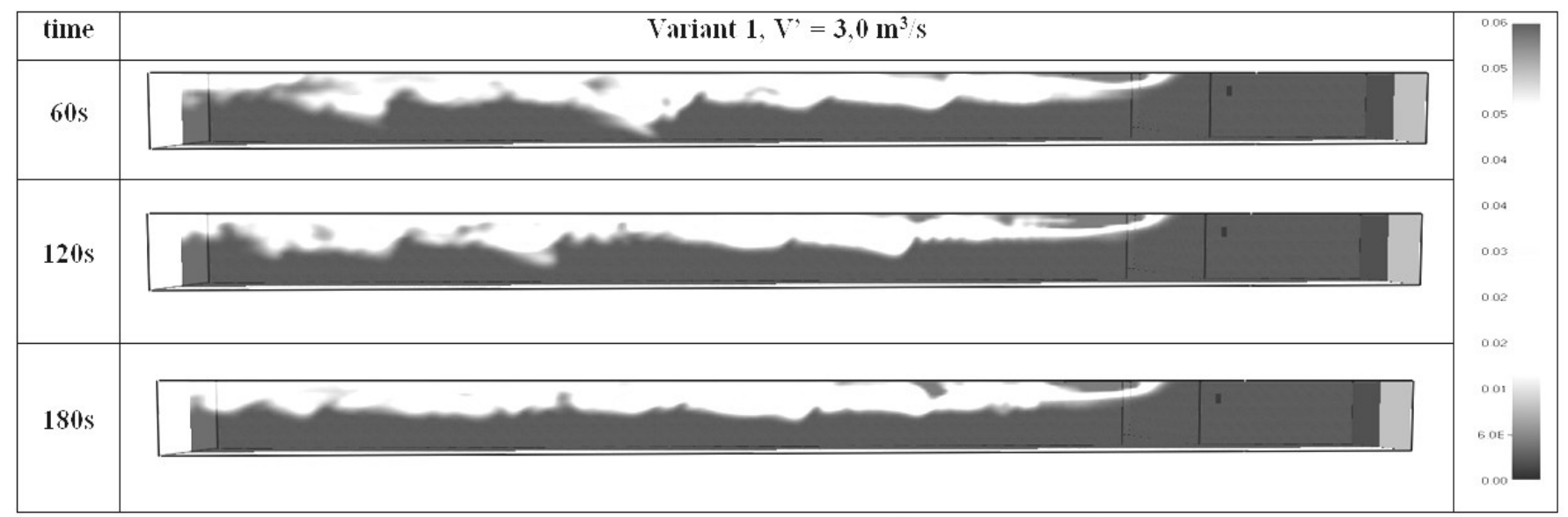

Fig. 4 The results of $\mathrm{CH}_{4}$ concentration in excavation no. 1 for variant 1

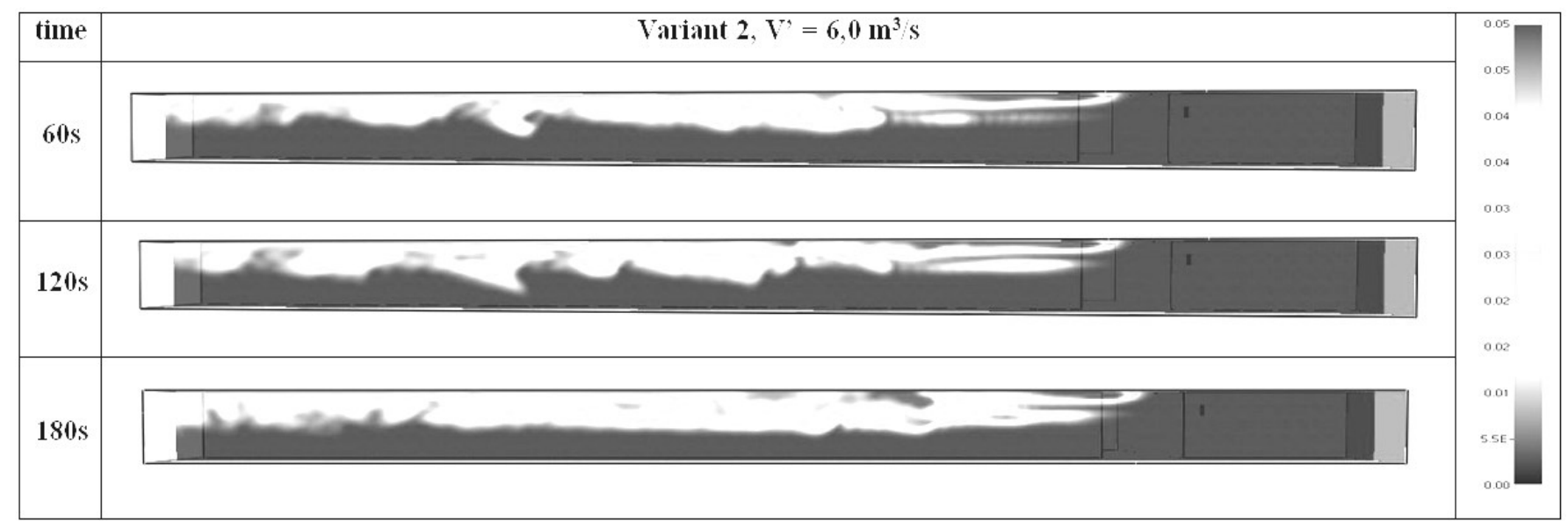

Fig. 5 The results of $\mathrm{CH}_{4}$ concentration in excavation no. 1 for variant 2 


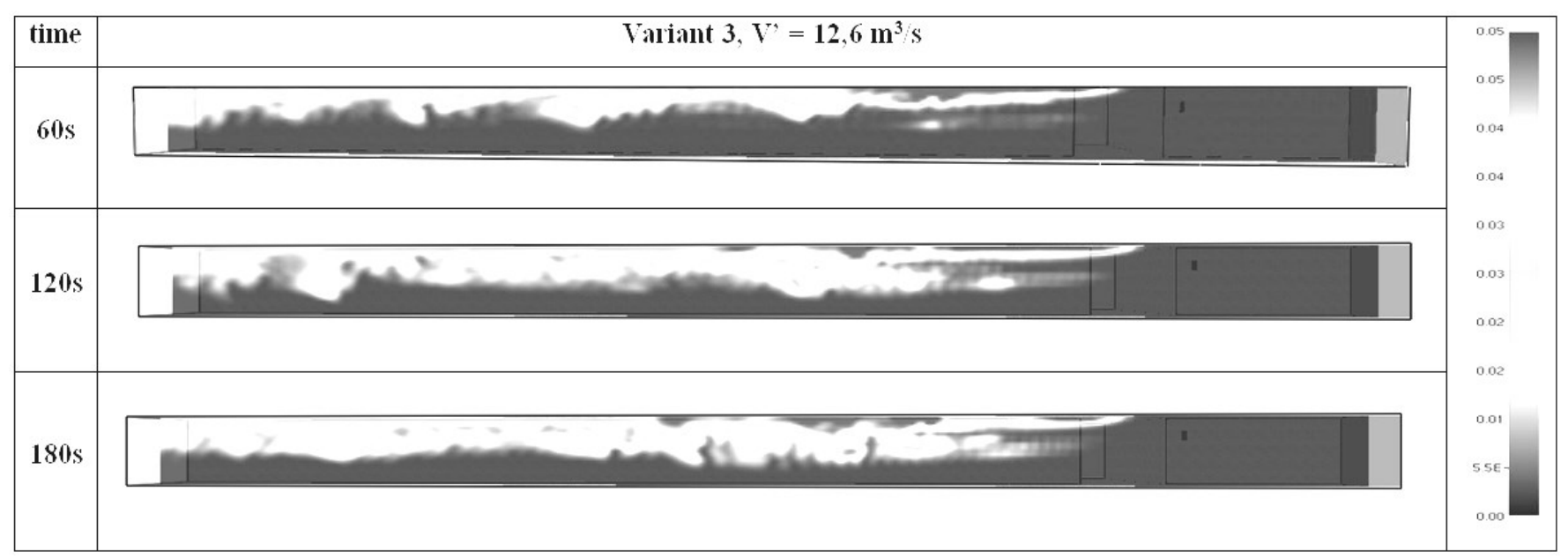

Fig. 6 The results of $\mathrm{CH}_{4}$ concentration in excavation no. 1 for variant 3

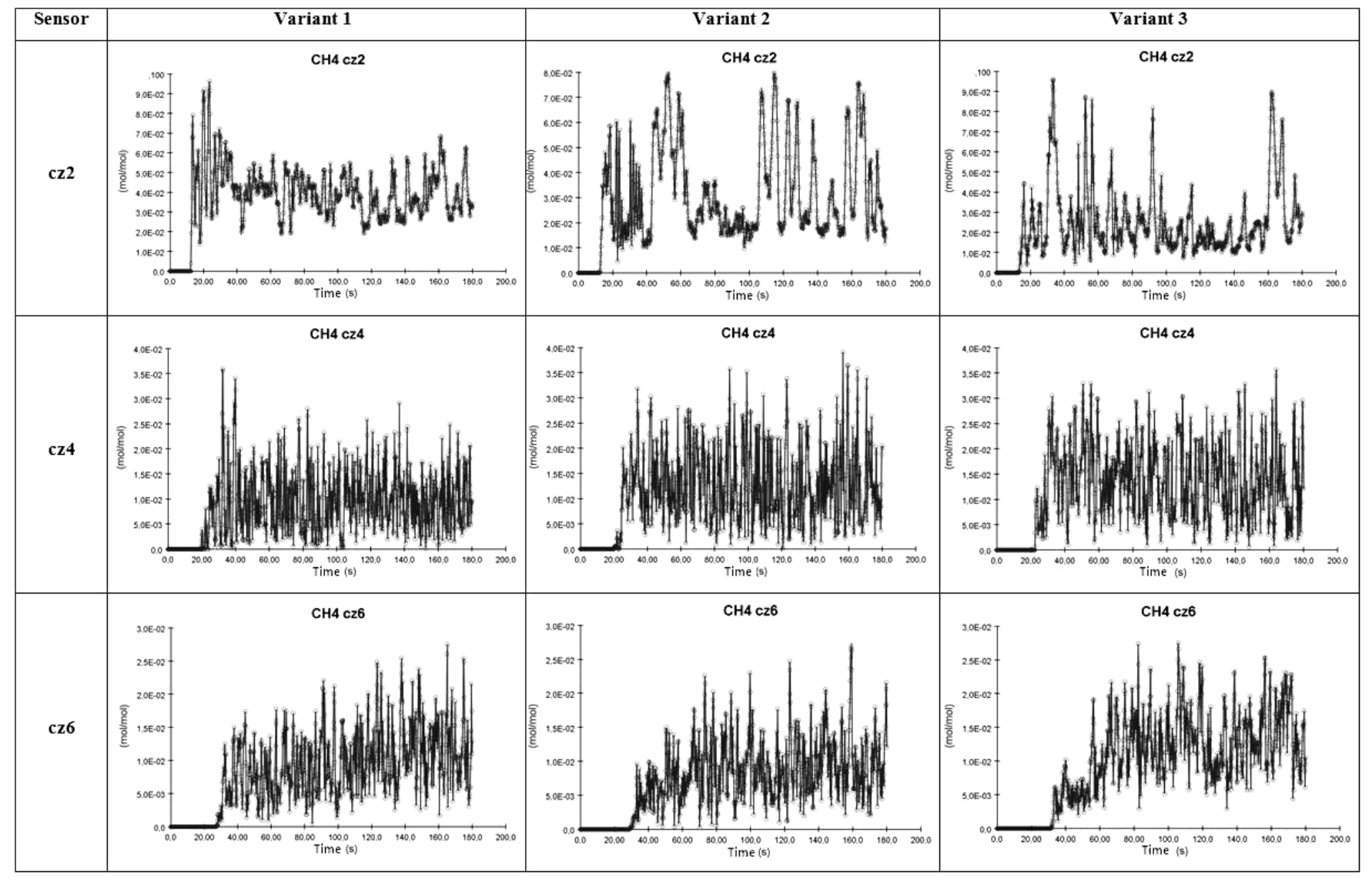

Fig. 7 Concentration of $\mathrm{CH}_{4}$ obtained at sensors no. cz2, $\mathrm{cz} 4$ and $\mathrm{cz} 6$ for different variants of simulation

Concentration of methane in the excavation no.1 at the slice $X=2.6 \mathrm{~m}$ for three variants after 60 seconds, $120 \mathrm{sec}-$ onds and 180 seconds is shown in Figures 4, 5, 6. Maximal concentration of methane was $6 \%$ vol. for variant 1 whereas for variant 2 and 3 it was $5 \%$ vol $\left(\mathrm{LEL}\right.$ of $\left.\mathrm{CH}_{4}\right)$.

Analyzing three variants it was found that methane layer is present always under the roof at the distance from the cross till the end of the excavation no. 1 . The range of methane - air mixture, their shape and methane concentration variability depend on the variant. It can be observed that for every variant, methane - air mixture fills up the excavation in some parts at more than a half of its height, measuring from the roof.

The Figure 7 gives the diagrams obtained from assumed methane sensors (numbers cz2, cz4 and cz6). Sensor cz2 is located at the cross, sensor cz4 is located in the half of the distance between the cross and the end of the excavation no. 1 Sensor 6 is mounted $1.0 \mathrm{~m}$ before the end of the excavation no. 1. All the sensors are at height of $3.0 \mathrm{~m}$.

For variant 1 , sensor $\mathrm{cz} 2$ indicated methane concentration $10.0 \%$ vol. after 20 seconds of simulation. Then concentration varied between $2 \%$ vol. and $6.5 \%$ vol. starting from 30 seconds of simulation up till the end (180 seconds). Average concentration was $4.8 \%$ vol.

For variant 2 , sensor $c z 2$ indicated maximal methane concentration $8.0 \%$ vol. three times, after 50 seconds, 120 seconds and 170 seconds. In other periods of simulation methane concentration varied between $2.0 \%$ vol. and $7.0 \%$ vol. Average methane concentration was between $3.0 \%$ vol. and $4 \%$ vol. 
For variant 3, sensor cz2 indicated maximal methane concentration $10 \%$ vol. after 30 seconds, and then three times $9 \%$ vol. after 45 seconds, 50 seconds and 160 seconds. In other periods methane concentration varied between $1.0 \%$ vol. and $6.0 \%$ vol. Average methane concentration was $3.0 \%$ vol.

Considering sensor $\mathrm{cz} 4$, for the first variant maximal methane concentration was $3.7 \%$ vol. after 30 seconds. Then methane concentration varied between $0.0 \%$ vol. and $3.0 \%$ vol. Average methane concentration was approximately $1.4 \%$ vol. For the same sensor, during variant 2 , maximal methane concentration was $3.9 \%$ vol. after 158 seconds. In other periods methane concentration varied between $0 \%$ vol. and $3.5 \%$ vol. Average methane concentration was $1.5 \%$ vol.

During variant 3 , sensor cz4 detected maximal methane concentration $3.6 \%$ vol. after 162 seconds. In other periods methane concentration varied between $0.0 \%$ vol., and $3.4 \%$ vol. Average methane concentration was $1.5 \%$ vol.

The sensor cz6 in variant 1 gave maximal concentration of methane $2.8 \%$ vol. after 163 seconds. Then methane concentration varied between $0.0 \%$ vol. and $2.5 \%$ vol. Average concentration of methane was from $0.6 \%$ vol. to $1.1 \%$ vol. In variant 2 maximal concentration of methane was $2.7 \%$ vol. after 158 seconds. Then methane concentration varied between $0.0 \%$ vol. to $2.6 \%$ vol. Average methane concentration was $0.5 \%$ vol. do $1.2 \%$ vol. In variant 3 maximal concentration of methane was $\mathrm{CH} 4=2.7 \%$ vol. after 82 seconds. Then methane concentration varied between $0.4 \%$ vol. and $2.5 \%$ vol. Average methane concentration was from $0.5 \%$ vol. to $1.5 \%$ vol.

\section{CONCLUSIONS}

The process of air streams mixing up at the intersection of two excavations when one of the streams has significant concentration of methane was the aim of numerical simulations. They were undertaken in FDS software, which belongs to CFD group of programs. It was assumed that air mixing should be supported by a jet fan mounted under the roof in vicinity of the cross. Three variants due to speed of the air generated by the fan were set up. Putting the results into the analysis, following conclusions were drawn:

In every variant the jet fan makes dilution of methane flowing from excavation no. 2. (e.g. Fig. 3), however the level of dilution and methane concentration in the excavation no. 2 after 180 seconds strongly depend on air velocity generated by the fan. Considering the area of the excavation no. 1 (at the cross), the most advantageous situation is when air velocity given by the fan is the lowest (variant 1 ), and the worst in variant 3 (the highest air velocity). Independently on the variant, considering the excavation no. 1 methane concentration equaled $2.0 \%$ vol. is exceeded only at fractional area under the roof.

Looking into the results obtained at slice in the excavation no. 1 (longitudinal cross-section) (Fig. 4-6) - the concentration of methane up to $6.0 \%$ vol. was noticed in variant 1 , and the concentration of methane up to $5.0 \%$ vol. in variants 2 and 3 . Methane was detected at entire distance of the slice from the cross till the end of the excavation . Concentration of methane varies dependently on the variant, although variants 2 and 3 should be considered as more proper because of not exceed of low explosive level of methane (LEL).
Analyzing the methane concentrations obtained at sensors cz2, cz4 and cz6 (Fig. 7) it can be observed that the lowest average methane concentration ( $2.5 \%$ vol.) was detected at the sensor cz2 in variant 3, however, the lowest maximal concentrations in variant 2 . Considering sensor cz4 average concentrations vary from $1.0 \%$ vol. to $1.5 \%$ vol. and maximal are approximately $3.8 \%$ vol.). Average methane concentrations at sensor $\mathrm{cz} 6$ are from $0.5 \%$ vol. to $1.5 \%$ vol. and maximal values of methane concentration do not exceed $3 \%$ vol.

The work is done with application of academic license for Pyrosim software which was provided by Stigo sp. z.o.o., ul. Ostatnia 1c. 31-444 Kraków, Poland.

\section{REFERENCES}

[1] D.A. Anderson, J.C. Tannehill and R.H. Pletcher. Computational Fluid Mechanics and Heat Tranfer. Philadelphia: Hemisphere Publishing Corporation, 1997.

[2] M. Branny. "Numerical simulation of airflow in blind headings ventilated with jest fans", in Archives of Mining Sciences, vol. 48(4), 2003, pp. 425-443.

[3] M. Branny. „Computer Simulation of flow of air and methane mixture in the longwall - return crossing zone", in Archives of Mining Sciences, vol. 51(1), 2006, pp. 133-145.

[4] M. Branny et al. „Eksperymentalna weryfikacja modeli CFD stosowanych w wentylacji kopalń", in Przeglqad Górniczy, vol. 69(5), 2013, pp. 73-82.

[5] J. Brodny and M. Tutak. „Zastosowanie numerycznej mechaniki płynów do analizy przepływu strumienia powietrza przez wyrobisko górnicze z ogniskiem pożaru”, in Przeglqd Górniczy, vol. 71(2), 2015, pp. 20-28.

[6] W. Dziurzyński and P. Skotniczny. „Badania dynamiki zmian stężenia metanu $\mathrm{w}$ chodniku korytarzowym z zastosowaniem metod numerycznej mechaniki płynów", in Przeglqd Górniczy, vol. 62(10), 2006, pp. 1318.

[7] J. Krawczyk. „Symulacja komputerowa zaburzeń przepływu w rejonie ściany wywołanych przez wyrzut gazów i inne przyczyny", in Przeglqd Górniczy, vol. 66(5), May 2010, pp. 17-23.

[8] T. Maciak and P. Czajkowski (2015, February). Modelowanie rozwoju pożaru w pomieszczeniach zamkniętych, cz.1 Model matematyczny [Online]. Available: http://www.inf.sgsp.edu.pl/symulacje/cwiczenia/ materialy

[9] K. McGrattan et al. (2013, November). Fire Dynamics Simulator (Version 5) Technical Reference Guide, Volume 1: Mathematical Model [Online]. Available: http://nvlpubs.nist.gov/nistpubs/SpecialPublications/ NIST.SP.1018e6.pdf

[10] M.J. McPherson. Subsurface Ventilation and Environmental Engineering, Springer Netherlands, 1993.

[11] T.X. Ren, J.S. Edwards and R.R. Józefowicz. „CFD Modeling of methane flow around longwall faces", in Proc. of the 6th Int. Mine Vent. Congress, Pittsburg, USA, 1997, pp. 247-251.

[12] P. Skotniczny. „Symulacja przepływu powietrza w wyrobiskach górniczych", in Przeglad Górniczy, vol. 61 (78), 2005, pp. 54-62.

[13] A. Strumiński and B. Madeja-Strumińska. „Predicting Basic Aerological Hazards in Underground Mines", in Archives of Mining Sciences, vol. 53(4), 2008, pp. 487497. 
[14] J. Sułkowski. „Niektóre problemy wentylacji ścian w warunkach współwystępowania zagrożeń naturalnych", in Mat. Szkoły Eksploatacji Podziemnej, Szczyrk, 23-27 Febr. 1998, pp. 309-320.

[15] P. Wrona. „Wpływ prędkości powietrza na rozwój pożaru egzogenicznego w wyrobisku górniczym - symulacja w programie Fire Dynamics Simulator (FDS) Pyrosim", in Przeglqad Górniczy, vol. 69(7), 2013, pp.117-124.
[16] P. Wrona and Z. Różański. Pomiar stanów i analiza przemian cieplnych powietrza, Gliwice: Wydawnictwo Politechniki Śląskiej, 2013.

dr inż. Paweł Wrona, dr inż. Zenon Różański

dr inż. Grzegorz Pach, mgr inż. Lech Domagała

Silesian University of Technology, Faculty of Mining and Geology

ul. Akademicka 2, 44-100 Gliwice, POLAND

e-mail: pawel.wrona@polsl.pl 